3-2019

\title{
Clientelism and Planning in the Informal Settlements of Developing Democracies
}

Chandan Deuskar

University of Pennsylvania, cdeuskar@upenn.edu

Follow this and additional works at: https://repository.upenn.edu/cplan_grad_pubs

Part of the Urban, Community and Regional Planning Commons

Deuskar, Chandan, "Clientelism and Planning in the Informal Settlements of Developing Democracies" (2019). Graduate Student Research (City and Regional Planning). 1.

https://repository.upenn.edu/cplan_grad_pubs/1

This paper is posted at ScholarlyCommons. https://repository.upenn.edu/cplan_grad_pubs/1

For more information, please contact repository@pobox.upenn.edu. 


\title{
Clientelism and Planning in the Informal Settlements of Developing Democracies
}

\begin{abstract}
The informal provision of benefits to the poor in exchange for political support, known as clientelism, often provides access to land and services for the urban poor in informal settlements in developing democracies. This review of multidisciplinary literature finds that while clientelism provides the urban poor with some access to the state, its benefits are often inadequate and inequitable. This kind of informal provision also disincentivizes or interferes with the implementation of formal plans. The literature provides some examples of transitions away from clientelism, but lessons for planners in facilitating such transitions are elusive.
\end{abstract}

\section{Disciplines}

Urban, Community and Regional Planning 


\title{
Clientelism and Planning in the Informal Settlements of Developing Democracies
}

\author{
Accepted at Journal of Planning Literature, March 2019.
}

Chandan Deuskar

Doctoral Candidate

Department of City \& Regional Planning,

School of Design,

University of Pennsylvania

cdeuskar@upenn.edu 


\begin{abstract}
The informal provision of benefits to the poor in exchange for political support, known as clientelism, often provides access to land and services for the urban poor in informal settlements in developing democracies. This review of multidisciplinary literature finds that while clientelism provides the urban poor with some access to the state, its benefits are often inadequate and inequitable. This kind of informal provision also disincentivizes or interferes with the implementation of formal plans. The literature provides some examples of transitions away from clientelism, but lessons for planners in facilitating such transitions are elusive.
\end{abstract}




\section{Introduction}

Urban planning has struggled to engage effectively with informality, and as a result has been unable to improve the conditions of the urban poor at the scale necessary (Mitlin 2013). By 2020, nearly 900 million people are expected live in informal or substandard urban settlements around the world (UN-Habitat 2010). National governments and international organizations often see the problem of informal urbanization as arising from a lack of planning, and call for resources to build planning capacity (Asian Development Bank 2013; Government of India 2013; Lall 2013; Lall, Henderson, and Venables 2017; Ozlu et al. 2015; United Nations 2016). For example, the Government of Kenya’s 2030 strategy for Metropolitan Nairobi aims to “plan, plan, plan” (Klopp 2012). According to urban sociologist Lisa Bjorkman, "[t]he notion that slums arise from lack of planning, and must therefore be prevented and upgraded using planning-related tools, has become a veritable battle-cry" across the rapidly growing cities of the 'Global South' (2014b, 37).

However, others have argued that simply planning more is not the solution, and that planning, as it has been practiced in low- and middle-income countries, may in fact have caused more problems than it has solved (B. Patel 2015; UN-Habitat 2009). Several authors have pointed to ways in which planning has helped to create and perpetuate informality (Bhan 2016; Datta 2012; Davis 2014; Roy 2012). When the state has tried to assert itself in cities dominated by informality through planned interventions, it has often done so in the form of 'mega-projects' that do not benefit the poor (Follmann 2015; Huchzermeyer 2011). Planners working among the urban poor have also been criticized for prioritizing economic growth over the immediate needs of the poor, valuing their own professional knowledge over that of poor communities, and offering simplistic solutions that fail to account for the sociopolitical complexity of informal settlements (Satterthwaite and Mitlin 2013). 
Most would accept that in rapidly urbanizing countries there is a legitimate role for the state in performing some urban planning functions, i.e. preparing and coordinating the provision of urban public goods. Yet, given past failures, it is clear that simply adding more resources for urban planning is unlikely to be effective, and that there needs to be a reformulation of planning theory and practice, in order for it to adapt to the context of rapid informal urbanization in the $21^{\text {st }}$ century (Watson 2009; UN-Habitat 2014).

\section{The politics of urban informality}

Urban informality has been described as a 'way of life' (AlSayyad 2004; Birch 2017), as it characterizes how the urban poor live, work, and get around. There is little scholarly consensus on a precise definition of 'informality'. Indeed, the recently published Global Encyclopaedia of Informality opens with the claim that informality is indefinable, saying that "it would probably be difficult to agree on a definition of informality acceptable to all." Instead, the publication uses the word 'informality' as “an umbrella term for a variety of social and cultural phenomena that are too complex to be grasped in a single definition", but which broadly refers to "the world's open secrets, unwritten rules and hidden practices" (Ledeneva 2018, 1). McFarlane and Waibel (2012) discuss various ways in which informality has been conceived: as a spatial category (the 'slum'), an organizational form (characterized by spontaneity and tacit knowledge rather than explicit rules), a governmental tool (which enables certain modes of intervention), and a 'negotiability of value' (shaped through shifting social relations). To anthropologist Julia Elyachar, 'informal' practices "have a legitimacy that is not the state's", even though the state may be implicated in perpetuating informality (Elyachar 2005, 67-69). Urban informality can take many forms, but usually involves

practices pertaining to land use, construction, utility connections, waste management, and transportation that do not conform to regulations but are generally tolerated. 
While urban informality may appear unplanned, haphazard, and chaotic, in fact an underlying order exists which is governed by complex but well-established social and political relationships (Chalana and Hou 2016). Political relationships between authorities and communities living in informal settlements in developing democracies are often 'particularistic', meaning that they involve the distribution of benefits by public authorities to specific individuals or small groups in direct exchange for money or political support, rather than 'programmatic' distribution of public goods without any direct deal-making. Particularistic relationships may take the form of corruption, which is the exchange of benefits by public officials for money, or clientelism, the exchange of benefits for political support (Herrera 2017). (Some authors, e.g. Kitschelt and Wilkinson (2007) use the terms clientelism and patronage interchangeably. Piliavsky (2014) suggests that the term patronage is used by anthropologists to refer to the same thing that political scientists term clientelism. Others, like Herrera (2017), use patronage to mean specifically the particularistic distribution of public sector jobs.) The urban poor lack the resources to engage in corruption on a large scale, but in democracies they do have votes, and so they engage in clientelism to negotiate for access to land and services.

Capacity constraints and the neoliberal withdrawal of the state may partially explain the emergence of informality and the non-enforcement of regulations by the state, but in the developing democracies of Asia, Latin America, and Africa, informality persists because powerful actors, including state actors, have learned to benefit financially and politically from it, and thus have a disincentive to effect change, as this paper explores. This suggests that in order for planners to work effectively in informal contexts, they must develop a much more sophisticated understanding of informal political practices such as clientelism, and the ways in which they shape cities in general and informal settlements in particular. These forces frequently undermine formal 
planning efforts, and are arguably more responsible for the limited impact of planning than lack of technical training, funding, technology, public participation, or 'political will' (Awal and Paller 2016; Gandhi 2012; Gandy 2006; Goodfellow 2012; Holland 2017; UN-Habitat 2014).

This article surveys the multidisciplinary literature on clientelism in informal settlements in developing democracies, with a focus on relatively recent work (from the 1990s onwards). While political dynamics vary greatly from one time and place to another, this article highlights common themes that emerge from the literature across contexts. The following section aims to help urban planners and policymakers understand how clientelism in informal settlements operates, what aspects of it benefit and hurt the poor, and how it may interfere with the implementation of formal plans. The subsequent section explores transitions away from clientelism around the world and discusses whether there are lessons that planners might learn from these examples. The conclusion points to gaps in the literature which future planning research might fill in order to further inform planning practice and urban policy in these environments.

\section{Clientelism in informal settlements}

Clientelism among the urban poor is "broadly accepted to be ubiquitous in the Global South" (Satterthwaite and Mitlin 2013, 61). Political scientists, anthropologists, sociologists, and others, including some planning scholars, have researched clientelism in poor urban settlements extensively, including in South Asia (e.g. Auerbach 2016; Banks 2016; Benjamin 2005; Björkman 2014a; Chidambaram 2011; de Wit 2017; Hackenbroch and Hossain 2012; Inskeep 2011; Jha, Rao, and Woolcock 2005; Nahiduzzaman 2006), Southeast Asia (Hutchison 2007; Tomsa and Ufen 2013), Sub-Saharan Africa (e.g. Adam 2013; Awal and Paller 2016; Bénit-Gbaffou 2012; Fox 2014; Gandy 2006; Levenson 2017; Paller 2014, 2016, 2017; Robins 2008; Rajack et al. 2013),

and Latin America \& the Caribbean (e.g. Álvarez-Rivadulla 2017; Auyero 2000; Gay 2006; Gray 
2004; Holland 2017; Herrera 2017; Weitz-Shapiro 2012; Shefner 2006). Some of these scholars discuss planning, but usually to comment on the role of planning in the eviction of informal settlers, rather than to discuss how planning could operate more effectively in a clientelistic environment. International development institutions which promote urban planning in the developing world, like the World Bank, have discussed clientelism in the contexts of service delivery (World Bank 2003) and governance (World Bank 2017) but not urban planning.

Clientelism involves the provision of private (or 'club') goods to the poor in contingent exchange for political support. Clientelistic relationships in urban areas are typically mediated through brokers. Each of these elements of clientelism is discussed below:

- 'Private or club goods':

In rural areas the goods distributed by patrons may be purely private (e.g. food, clothes), but in dense urban settlements, these goods are often 'club' goods which benefit the residents of a particular neighborhood, like water pipes, electrical connections, sewerage, or paved roads (Burgwal 1995; Rojo, Jha, and Wibbels 2014). For example, several accounts of clientelism discuss water provision in informal settlements, e.g. in several cities in India (Björkman 2014a; De and Nag 2016; de Wit and Berner 2009; Weinstein 2014), as well as in Pakistan (Inskeep 2011), Mexico (Herrera 2017), and Nigeria (Gandy 2006). The fact that urban clientelism involves the provision of urban services makes it a competitor of, or supplement to, the provision of services through planned networks or policies. 
The other private or club good that patron-client relationships provide in informal settlements is land. Political patrons may own or otherwise control land and distribute it as a private good to clients. For example, politicians or government officials own over half the land in Kibera, the large informal settlement in Nairobi (Syagga, Mitullah, and Karirah-Gitau 2002, cited in Fox 2014), and these figures or their brokers informally allocate plots of land to residents. Perhaps more commonly, politicians protect informal settlements from demolition after they have formed, which acts as indirect provision of land (Álvarez-Rivadulla 2017; Benjamin 2008; Holland 2017). Fox (2014) and Gillespie (2017) describe national political party leaders in Tanzania and Ghana respectively insisting that local authorities call off demolitions of informal settlements, in order to protect their party's popularity. According to Huchzermeyer (2011), "the modalities of patronage and exploitation $[\ldots]$ are part of the reason why, despite hostility, threats, sporadic evictions and even large-scale displacement, informal settlements have continued to exist in most African cities" (26). Informal settlers sometimes plan their actions around these dynamics. For example, Burgwal (1995) describes how leaders from among the urban poor in Quito, Ecuador, waited several months before initiating a planned 'land invasion' on vacant private land, so that the invasion would coincide with an election campaign during which they knew they would receive political support.

The late Pakistani activist Perween Rehman argued that, in Karachi, "the government, the political parties, the police, the members of the national assembly, [and] the councilors" are all involved in land grabbing to set up organized squatting. In the absence of adequate 'formal' land supply, she argued, these informal land grabbers are really "land suppliers", who provide land, infrastructure, and services to the poor, which in her view makes the municipality and planners redundant (Inskeep 2011, 105). Khan (1992) notes that informal settlements in Karachi often grow in size and number just before elections. 
- 'To the poor':

Clientelism involves asymmetrical power relationships, with those distributing the goods in positions of greater power or authority than those receiving them. Some authors (Holland 2017) explicitly include a 'progressive' element (i.e. benefits going disproportionately to the poor) as a defining criterion of clientelism, but even when this is not explicit, the recipients of clientelistic goods in the literature are usually the relatively poor, whose needs can be affordably met by patrons (Muller 2007).

\section{- 'Contingent exchange':}

To be considered clientelism, an exchange must involve mutually contingent reciprocity, i.e. the community provides political support only if the patron has already provided benefits or can credibly commit to providing future benefits, and vice versa: the patron provides benefits only if a community has demonstrated or credibly promised political support (Álvarez-Rivadulla 2017; Holland 2017). Maintenance of the relationship depends on mutual monitoring. The provision of the same benefits to a poor community that is not directly contingent on political support would simply be an instance of welfare, 'constituency service', or 'pork-barrel politics', rather than clientelism. Nonetheless, some authors note that despite the contingent nature of clientelism, it need not simply involve a one-off quid pro quo exchange, and may involve the cultivation of longterm relationships built on iterative problem-solving and the gradual building of trust (Muller 2007). Recent scholarship also notes that patrons often monitor voting in poor urban settlements not at the individual level but at the level of the neighborhood or voting booth, and that, as mentioned above, benefits are not specifically targeted to private households but are loosely targeted to entire neighborhoods, putting this kind of exchange more in the realm of 'pork-barrel 
politics' than traditional clientelism (Auerbach et al. 2017). This article uses the term 'clientelism' broadly, to include these variations.

\section{- 'Political support':}

Clientelism is sometimes described as election-time 'vote-buying' or, particularly in South Asia, 'vote bank politics'. While voting is central to clientelistic exchange, communities may also demonstrate support in other ways, such as attendance at political rallies in large numbers (Björkman 2014a; Herrera 2017; Auyero 2000; Kramon 2016).

\section{- 'Through brokers':}

Political 'brokers' in informal settlements may be agents of parties or politicians entering informal settlements from the outside, but they often are the opposite: leaders of poor communities selected and promoted from within to forge political connections and channel benefits to the informal settlement. This was a finding of a study by Auerbach and Thachil (2014) which surveyed residents in 110 informal settlements in two Indian cities, leading the authors to argue that the "bottom-up construction of informal slum leadership demands that we take the agency of residents seriously in explaining the rise and mechanics of patron-client networks" (3-4). This view is supported by sociologist María José Álvarez-Rivadulla's (2017) study of squatting in Montevideo, Uruguay. She describes one broker who cultivated connections to several political parties and, as he himself put it, 'flirted' with many politicians before establishing a relationship with one on behalf of his community (157). Another community leader in a Montevideo informal settlement approached a political contact of hers in the municipality and (as she later recalled) bluntly stated: "[T]he campaign is coming and if you want votes, come down to earth: I need water for my people" (57). 
Depending on how competitive the political landscape is, political candidates may compete to win the favor of such brokers before elections, with the expectation being that residents of informal settlements vote in blocs, as directed by their leaders. Álvarez-Rivadulla and others describe this as 'market clientelism'. For example, anthropologist Robert Gay describes how during one election in Rio de Janeiro, two candidates made competing offers to the president of a neighborhood association in a favela prior to an election: one offered sets of soccer shirts, the other promised the construction of toilets in a preschool in the settlement. The association president negotiated with the latter candidate for six weeks before agreeing on a budget for the construction. As soon as a check was handed over for the construction of toilets, the neighborhood association president publicly endorsed the candidate and accompanied him on door-to-door visits around the settlement. According to Gay, the politician's policies or his party's platform did not even need to be mentioned during these visits (Gay 2006). However, clientelism does not always feature this level of competition. Bénit-Gbaffou (2012) notes that while clientelism exists in informal settlements in Johannesburg, South Africa, the dominance of the African National Congress (ANC) party limits the options available, and does not force accountability on the part of patrons to the extent seen in the examples that Gay discusses.

\section{Benefits of clientelism to the urban poor}

For the poor, patron-client relationships are often the only means of accessing the power of an otherwise unresponsive state (Auerbach and Thachil 2014; Auyero 2000; Chidambaram 2011; Jha, Rao, and Woolcock 2005; Mitlin 2014; Robins 2008). Patrons and politically wellconnected brokers may benefit politically from their local power as well, but in exchange they are often highly receptive to the needs of the communities, building trust over time by developing personal relationships with households (Auyero 2000; de Wit 2017). Describing clientelism in an 
informal settlement in Buenos Aires, sociologist Javier Auyero (2000) relates examples of brokers distributing food and medicine to residents, holding 'office hours' to listen to residents' complaints and requests, even arranging to take schoolchildren to the beach. In her landmark 1976 study of favelas in Rio de Janeiro, Perlman (1976) mentions political brokers negotiating collective benefits like sewerage and cement steps. Burgwal (1995) describes how clientelism gave a Quito settlement access to electricity, a paved road, a market place, bus service, and sewerage. Sociologist Lisa Björkman, describing an informal settlement in Mumbai, India, notes how "everyday activitiesaccessing municipal water; applying for or renewing identity documents $[\ldots]$; getting a child registered for school; applying for a school-fee waiver; registering a birth, marriage, or death in the family; starting a business; disposing of garbage; unblocking gutters; taking out a low interest loan - generally require mediation by someone who can provide needed information and technical assistance" (Björkman 2014a, 621). This assistance is eagerly provided by patrons and brokers.

Residents of informal settlements often see political patrons and brokers in positive terms. For example, according to Auyero (2000), the urban poor in Argentina view political brokers as “'helpful' and 'sacrificing' and 'good people' with whom problem holders have a personal relationship sometimes described as 'friendship"' (74). The personal nature of these relationships is critical. Álvarez-Rivadulla (2017) recalls being surprised early in her career to find that the urban poor in Montevideo referred to high-ranking state officials by their first names and had their phone numbers in their home directories (26-27). In a study of urban Ghana, political scientists Awal and Paller argue that "[e]veryday interaction is a crucial - but poorly understood - component of how accountability is generated between leaders and citizens in the absence of formal mechanisms" $(2016,8)$. This personal relationship means that the support provided by the poor to these political 
figures is often motivated by a sense of obligation or gratitude rather than a transactional exchange of votes for services.

In her book Forbearance as Redistribution, political scientist Alisha Holland (2017) argues that the selective non-enforcement of the law by authorities (which she terms 'forbearance'), such as the law against squatting, acts as a form of redistribution of resources like land to the poor. As a means of redistribution, this selective non-enforcement is much less expensive and more credible than other forms of welfare like public housing construction or state-sponsored land distribution. According to Brusco et al, a minority of political scholars defend clientelism as "sort of a poor country's welfare state. Reform such systems too soon, the minority [of scholars] asserts, and you run the danger of depriving 'clients' of the only organizations and networks capable of responding to their needs. The alternative to vote buying, this argument runs, is not programmatic democracy but mass neglect" (Brusco, Nazareno, and Stokes 2004, 84). Similarly, Mitlin notes that while much of the literature is critical of the role of clientelism in informal settlements, others argue "that it has been dismissed with neither a considered analysis of what it has managed to deliver nor a grounded assessment of what might take its place" (Mitlin 2014, 3). Gay (1998) argues that "under certain circumstances, clientelism plays a positive and largely unheralded role in the process of democratic consolidation" (7).

\section{Costs of clientelism to the urban poor}

It is important to note the benefits of clientelism described above in order to understand why residents of informal settlements may be reluctant to abandon the trust relationships with patrons and brokers they have built up over time in favor of an untested formal system of service provision, no matter how 'inclusive' or 'participatory' in its intent. Still, clientelism clearly does not represent an ideal system for the poor either, for several reasons. 
First, clientelism may produce worse outcomes for the poor than programmatic service delivery. Scholars argue that when the source of legitimacy of political players is clientelism, state effectiveness is undermined (Fergusson, Larreguy, and Riaño 2016; Goodfellow 2012; Herrera 2017). Studies of service provision in informal settlements in India (De and Nag 2016) and Pakistan (Shami and Majid 2014) find lower provision of public goods to households as a result of clientelism. Second, clientelistic service provision or protection may be unequally distributed, with the most disadvantaged groups being the ones least likely to benefit (Satterthwaite and Mitlin 2013). Third, clientelistic relationships may be marked by coercion and violence, especially if organized crime is active in the settlements, as noted in the case of Latin America (Davis 2014), India (Gandhi 2012), Jamaica, South Africa, and Bangladesh (Satterthwaite and Mitlin 2013). Fourth, clientelism locks residents of informal settlements into dependency, as political patrons have little incentive to allow the poor to independently access land and services (Benjamin 2005). Fifth, some see clientelism as exploitative. In the context of Brazilian favelas, da Silva and Shaw (2012) describe clientelism as harkening back to feudalism and slavery. Evidence from Mumbai and Nairobi suggests ways in which some powerful interests exploit informal settlers for their own ends, gaining control of land which formal plans have deemed unsafe or ecologically sensitive by first encouraging the poor to informally occupy it, only to force out or price out the settlers and sell the land to middle class residents or real estate developers once it has been accepted as residential land (Pethe et al. 2014; Rajack et al. 2013). This is ultimately against the interests of both the poor being used in this manner and of the city as a whole.

Lastly, clientelism is sometimes thought to stifle horizontal mobilization of the urban poor. Some argue that, in the absence of state provision of infrastructure and services at scale, clientelism simply "buys off, co-opts and absorbs pressure and protest from the urban poor" (Satterthwaite 
and Mitlin 2013, 63). According to de Wit and Berner (2009), "the poor, facing conditions of scarcity and competition, rely on vertical relations of patronage and brokerage which may hinder or prevent horizontal mobilization" (927). Studies of neighborhood organizations among the urban poor complicate this picture somewhat. Burgwal's study of an informal settlement in Quito (1995) and Álvarez-Rivadulla's study of squatting in Montevideo (2017) both argue that neighborhood organization and clientelism are not mutually exclusive but rather mutually reinforcing, as neighborhood organizations help strengthen the bargaining power of the poor and make it easier for patrons to engage with communities. Still, Satterthwaite and Mitlin (2013) note that such mobilization among the urban poor in a clientelistic environment remains highly local, with communities competing with each other to attract patronage (64). Even Burgwal acknowledges that while the community in Quito that he studied was able to use its collective power to successfully negotiate for a range of clientelistic goods, it probably did so at the expense of other neighborhoods, which reinforces the argument that clientelism undermines broad mobilization of the poor.

Research on South Africa in particular provides multiple examples of the role of clientelism in undermining mobilization in this manner. When authorities threatened the eviction of a Johannesburg settlement in 2010, the residents initially sought help from a rights-based nongovernmental organization (NGO), which began to work with them on resisting the eviction. However, when the ANC stepped in and promised to preserve and refurbish their homes, the residents distanced themselves from the NGO, and denounced it as anti-national (Bénit-Gbaffou and Oldfield 2014). Robins (2008) explains how the efforts of Shack/ Slum Dwellers International (SDI) to produce horizontal networks of the urban poor in Cape Town were undermined by local leaders who were embedded in clientelistic politics and open to ANC patronage. In a discussion 
of how clientelism impacted the provision of resettlement housing in Cape Town, Levenson (2017) describes how the emergence of competing factions among potential beneficiaries was a boon to authorities who had promised housing to former squatters, as they were able to provide housing only to the best-organized faction and leave the others on a decades-long waiting list.

Even when the poor are aware of the ways in which their political patrons prevent them from independently accessing the benefits of the state, they have little choice but to accept this system, given the precariousness of their situations and their reliance on these patrons. According to De Wit and Berner (2009), for the poor, "relations of patronage and reciprocity that offer some security have to be maintained regardless of their long-term costs. To cut off links with exploitative patrons and intermediaries would imply foregoing all claims to emergency assistance" (931). In other words, the urban poor are stuck in a system that they know is failing them.

\section{Clientelism as a barrier to planning}

The responsibilities, legal status, and institutional location of the state's urban planning function varies from one country or city to another. Each context has its own 'planning culture', which evolves over time (Sanyal 2005), and non-state actors may also perform activities that involve planning. All this makes it difficult to talk about planning as a monolithic concept. Having said that, if we return to the definition of public-sector planning offered in the introduction, i.e. the state's role in preparing and coordinating the provision of urban public goods, it is clear that clientelism interferes with the ability of the state to plan. This definition of planning entails the provision of public (i.e. nonexcludable) goods, and a long-term vision. Planning also should also involve broad public participation in decision-making, which requires transparency. The logic of clientelism, which involves targeting of benefits to specific individuals or groups, in the short term, 
and in the form of nontransparent deal-making, is incompatible with all three of these aspects of planning.

In more practical terms, land use plans become meaningless when land that is reserved for streets, parks, or other public infrastructure, or land that is deemed too ecologically sensitive or hazard-prone to build on, is occupied by informal settlements with the support of powerful politicians. Similarly, medium-term plans for infrastructure cannot be implemented if the incumbent mayor unexpectedly diverts municipal resources towards an informal settlement in order to secure its votes for re-election. This is not to say that such formal plans would necessarily have positive outcomes for the poor if implemented, nor that clientelism is always bad for the poor (as discussed above), only to demonstrate the incompatibility between clientelism and planning.

Once clientelistic land and service provision is established, those who benefit from it oppose the entry of formal planning or of any program that provides universal access to basic services to formal and informal settlements alike (Fox 2014; Mitlin 2014). Diane Davis describes how, in Latin America, when planners turned their attention to informal settlements and tried to formalize them in the late $20^{\text {th }}$ century, "it was too little too late... [U]rban planners' room for manoeuvre was highly circumscribed, owing to the prior informal relations of brokerage that had flowered during earlier periods of state neglect. Even when they sought to introduce new urban projects into informal areas, planners were sometimes kept at bay by the local power brokers whose authority rested in the maintenance of a clear distinction between the formal and informal city" (Davis 2014, 386). This echoes Perlman's observations about community leaders in Rio's favelas who act as brokers: "If the squatter settlements were to achieve legal rights to their lands and full urban services and facilities, in many cases the usefulness, power, and importance of these leaders would be severely reduced... In order to survive, they must persuade residents to be content with 
token change and slow progress, and to trust that local leadership is doing its best to deal with the difficult problems of infrastructure and tenure. This may sound Machiavellian, but it is generally true" (Perlman 1976, 166-67).

Similarly, in the context of clientelism in informal settlements in Mexico, Herrera (2017) argues that "politicians fail to provide reliable and high-quality public services because they often benefit politically from manipulating public service provision for electoral gain.” Holland (2017) argues that once the post-hoc regularization of squatting is established as an informal welfare policy, both the poor and the state are locked into a 'forbearance trap', where the poor organize their demands around acceptance of informality rather than more involved forms of welfare (e.g. public housing provision), which, as a result, the state does not develop the capacity to provide.

\section{Transitions away from clientelism in informal settlements}

In what circumstances can residents of informal settlements transition away from clientelistic systems which do not meet their best interests and which prevent urban planning from being effective? Political scientists have suggested that clientelism declines as urbanization and income levels increase (Scheiner 2007), though this argument is of limited relevance in the context of already urban settlements where clientelism may in fact be keeping people in poverty, as discussed above. In the context of cities in Ghana, Nathan (2016) argues that while middle-class urban voters do prefer 'universalistic' policies to particularistic ones, neither middle-class voters nor politicians themselves believe that politicians can deliver such policies. As a result, politicians ignore these preferences and focus on particularistic exchanges with the poor, while members of the middle class disengage and abstain from voting altogether. To the extent that middle class

disengagement from voting is a pattern across developing democracies, this suggests that the growth of the middle class alone is unlikely to conquer clientelism. 
An established literature exists on the decline of clientelism in advanced democracies in North America and Europe. Traditional explanations for the mid-twentieth-century decline of 'bossism', the form that clientelism took in the United States, include increased access to education, which opened up better opportunities to urban youth for attaining wealth than local politics; lower immigration, which reduced the number of vulnerable and factionalized newcomers; reform in the civil service and in municipal accounting, which made irregular expenditures harder to hide; mass communication technology that made it more efficient to appeal to constituents beyond the neighborhood level (Shannon 1969); and New Deal federal welfare programs that undermined the power of local bosses (Lapomarda 1970). Hays (1974) emphasizes the role of professional and business elites in centralizing power in the city, removing it from wardand community-level bosses and placing it in the hands of municipal-level technocrats.

Naples, Italy, saw an end to clientelism in the 1990s, when corruption scandals destroyed Italy's long-incumbent Christian Democratic Party. Reforms followed, including the direct election of mayors, and a requirement that mayoral candidates win an absolute majority of votes. Whereas the previous coalition-based system allowed candidates to get a seat at the table by making deals for only a few thousand votes each, clientelistic procurement of votes was no longer possible at the scale necessary under the new system (Pasotti 2010).

The literature also yields a small number of more recent instances of transitions away from clientelism in developing democracies, which do not necessarily repeat the American and Italian experiences outlined above. The following section identifies and briefly describes such cases, in which clientelistic service delivery in informal settlements has given way to more 'programmatic' service delivery, and examines whether they hold any lessons for planning. 


\section{Crisis as an inflection point (Vidigal, Rio de Janeiro)}

Robert Gay describes a favela called Vidigal in Rio de Janeiro that managed to escape the confines of clientelistic service provision in the 1970s and 80s, and instead benefit from programmatic public works projects, which provided sewerage, drainage, and water infrastructure without making any voting deals with politicians. The impetus for this change was a threat of eviction that their usual political patron was unable or unwilling to fight. The leaders of Vidigal broke from the traditional clientelistic system and joined with NGOs and church groups to combat the threat, a move which "effectively eliminated the practice of clientelism in the favela" (Gay 2006, 205). From this point on, unlike in neighboring settlements in Rio, the leaders in Vidigal presented their demands not to local politicians in the informal settlements but more senior officials in city hall. Not only did neighborhood leaders no longer make deals with candidates, and in fact refuse to endorse candidates, but they even made a concerted effort to convince the residents that public works programs organized by political candidates did not obligate them to vote for their parties, because public services were their right regardless of their vote. While parties were still free to organize public works projects in the settlement, candidates were prohibited from campaigning on the basis of those projects, instead being invited to present their broader policy positions and platforms to the residents.

Gay is cautious in his appraisal of this apparent success, partly because the residents of Vidigal did apparently continue to electorally reward parties that had initiated public works in the favela. Gay labels this as 'semi-clientelism'. Still, he notes that they did not do so as part of a deal or under any coercion or pressure, but independently in response to parties whose actions had benefited them. 


\section{The role of local elite reformers during a broader political transition (Mexico)}

Herrera (2017) describes relatively successful reforms that changed water provision from clientelistic to programmatic systems in several cities in Mexico. These reforms occurred in the 1980s and 1990s, as part of a broader move towards market-oriented and democratic reforms that were initiated in cities where an opposition party had come into power in the local government, displacing the more autocratic party that had held power across the country for decades.

In the city of Leon (population 1.4 million), the local business community became actively involved in the water and sanitation sector following a severe water shortage. This prompted reform in the water sector, which resulted in the city's water utility becoming effectively independent of political interference. The reform of the utility focused on charging user fees, and at times appeared to favor the business interests which were represented on the board, which led to protests from poor communities. Still, service delivery improved citywide, and became less

clientelistic in nature. Similarly, in Irapuato (population around half a million), the same newly incumbent reform party moved the water utility towards cost recovery as a means of breaking clientelistic ties between the former incumbents and residents, which had involved low negotiated rates between the utility and community leaders in informal settlements. In both Leon and Irapuato, there was relatively broad participation in water reforms within elite groups.

Two other Mexican cities - Naucalpan and Celaya - were similarly successful in pursuing water utility reforms, but unlike the previous pair of cities, did so through much narrower coalitions of reformers. Reforms in both cities were led by mayors rather than broader groups of elites, but as in Leon and Irapuato, reforms were geared towards collection of user fees, which led to protests that eventually subsided, leaving less politicized service provision. 
These experiences contrast with those of four other Mexican cities studied by Herrera. In Toluca, Xalapa, Neza, and Veracruz, the newly incumbent parties preferred to retain or even expand the old clientelistic networks of water provision inherited from the former incumbents. Herrera uses these eight cities to argue that the presence of a strong middle-class political base as well as water-intensive industries were key factors in initiating and sustaining programmatic reform of water provision.

Herrera, like Hays in the US context, emphasizes the role of elite reformers in weakening clientelism. By contrast, Shefner (2006) explores the community-based 'anticlientelist' activism of an NGO called UCI (Union of Independent Settlers) which, in collaboration with Jesuit organizations and other NGOs, fought for better service provision in informal settlements in Guadalajara. However, Shefner observes that UCI lost its momentum once it became formally involved in electoral politics itself.

\section{Broad political reform and fiscal crisis (Bogota, Colombia)}

Bogota, a city in which nearly 40 percent of the land area is occupied by informal settlements, also experienced a shift away from rampant clientelism in the 1990s. According to Pasotti (2010), the introduction of direct mayoral elections in 1986 set the conditions for reform, as they replaced the previous, highly centralized system in which Parliament was able to control the nomination of mayors. A new constitution was passed in 1991, which favored independent electoral candidates without party affiliations. Identification with established parties among the electorate declined rapidly, particularly in urban areas, which led to the collapse of the clientelistic political machine in Bogota. Campaigns now sought to mobilize public opinion in their favor instead of buying votes. Bogota also faced a fiscal crisis in the early 1990s, which led to several 
reforms that consolidated and strengthened the authority of mayors, and also prompted them to move away from clientelistic politics.

\section{The legacy of a technocratic dictatorship (Santiago, Chile)}

Holland (2017) describes the transition from politically supported squatting to public housing provision in Santiago, Chile. The early 1970s saw a spike in the formation of informal settlements, with 400,000 people participating in land invasions, often in relatively central and visible locations in the city. According to Holland, the refusal of the socialist government of the time to repress these invasions added to the sense of social chaos which culminated in the military takeover in 1974. The military dictatorship repressed new land invasions and initiated a formal housing subsidy program through a technocratic housing ministry. When Chile redemocratized starting in 1990, the democratic government took advantage of the existence of a technically competent housing ministry and used it to establish a housing program of its own, as a means of demonstrating that democracy could deliver public goods to the poor. In order to prevent squatting from re-emerging as a housing option for the poor, which would undermine the housing program, the new democratic continued to repress squatting.

\section{A move towards right-wing politics (Istanbul, Turkey)}

Holland also discusses the example of Istanbul, which also had a history of clientelistic support for informal settlements prior to 2002, when the conservative Justice and Development Party (AKP) came to power and began to dominate Turkish politics. It took advantage of Turkey's declining poverty rate, which meant that the median voter was no longer poor, and the fact that its political base was the majority Sunni population, which no longer formed the majority of urban migrants. The government was able to associate informality with Kurds, Roma, and other ethnic 
minorities. The ruling party's political fortunes did not rely on clientelistic ties to the urban poor, and the government proceeded to demolish informal settlements.

\section{Grassroots community organizations (multiple countries)}

In several countries, grassroots organizations have attempted to move communities away from clientelism. Mitlin (2014) and Satterthwaite and Mitlin (2013) analyze ways in which grassroots NGOs active among the urban poor in Asia and Africa have been partially successful in subtly shifting the balance of power away from clientelism. These organizations include the Orangi Pilot Project (OPP), which began in the Orangi settlement in Karachi with a focus on building neighborhood-level sanitation using community savings and labor; the Society for the Promotion of Area Resource Centres (SPARC), which later formed alliances with the National Slum Dwellers' Federation (NSDF) and Shack/Slum Dwellers International (SDI), and formed a women's saving group called Mahila Milan; and the Asian Coalition for Housing Rights (ACHR), which has been involved in urban upgrading in informal settlements across the Asian continent, especially since the launch of the Asian Coalition for Community Action in 2009. These three selfhelp organizations, all originally formed in the 1980s, have slightly different focuses and modes of operation, but share common features. They all tend to rely primarily on community savings to build neighborhood-level infrastructure. They are dominated by women, both in leadership roles and in the membership of savings groups, many of whom have never been involved in civic or community activities before.

Importantly for this discussion, activists in these organizations tend to be highly critical of clientelistic provision of services, understanding them to be insufficient, unreliable, unequal, and divisive (Mitlin 2014). Still, these organizations typically avoid contesting existing power structures through protest and confrontation. They instead empower themselves and loosen the 
hold of political patrons through more subtle strategies. Mitlin highlights three approaches which "encapsulate the essence of the strategy to address clientelism" (21). The first is the prevalence of women-led, alternate forms of organization such as savings groups, which are not seen by the political elite as threats, but which nonetheless are highly accountable to residents. Second, community-led mapping and surveying provides these organizations with information that is useful not only to themselves but to government officials. Third, these organizations form citywide networks of poor communities and other partners, which helps share information and practices, and strengthens the collective power of communities to bargain for rights.

These organizations do not claim to be self-sufficient, and recognize the need for government support in scaling up, but rather than angling for patronage, prefer to start with 'precedent-setting' projects that demonstrate the kinds of interventions they consider necessary (Mitlin 2014). This proactive approach is demonstrated in Patel et al's account of Mahila Milan's activities in Mumbai, India, which notes that community women developed housing prototypes themselves, and then invited senior government officials at the ward, city, and state level to view and consider implementing them (S. Patel, Arputham, and Bartlett 2016).

The extent to which grassroots organizations like these can eliminate clientelism altogether is debatable. Datta (2012) suggests that the work of Mahila Milan and another NGO in an informal settlement in Delhi, India, did in fact help to "connect working-class women to civil society organizations and subsequently move away from informal structures of patronage, privilege, and customary authority" (96-97). However, as noted earlier, other authors (Álvarez-Rivadulla 2017; Burgwal 1995) do not believe that mobilization among the poor necessarily helps transition away from clientelism, even if it helps the poor bargain more effectively for clientelistic benefits. A common theme across Diana Mitlin's work (Mitlin 2008, 2018; Mitlin and Mogaladi 2013) is that 
grassroots organizations tend to move opportunistically between various strategies, including openly contentious politics, collaboration with state actors, and subversion of state regulations, which suggests that they may not necessarily eschew clientelistic opportunities altogether. As Satterthwaite and Mitlin observe, "It is clearly not possible for a bottom-up process alone to either overcome clientelism or to provide the finance for universal solutions to be implemented" (197).

\section{Discussion: a role for planners?}

While each of the transitions away from clientelism discussed above took place in a specific political and institutional context, it is possible to identify some recurring features. Crises appear to have acted as inflection points in the movement towards change in Rio de Janeiro, Leon (Mexico), and Bogota. In Mexico, Colombia, Chile, and Turkey, as in Italy, the move away from clientelism is impossible to separate from broader political transitions in those countries, which had impacts far beyond informal settlements. The Chilean case involves a military coup, while the Turkish case involves repression and demonization of informal settlers, none of which is likely to be in the best interests of the poor. Beyond being opportunistic in capitalizing on broader conditions that support urban planning, lessons for planners are hard to discern from any of these examples.

It is easier to imagine urban planning playing a role in supporting the grassroots organizations and NGOs discussed above, including both the neighborhood organizations associated with individual informal settlements and national and transnational networks like OPP,

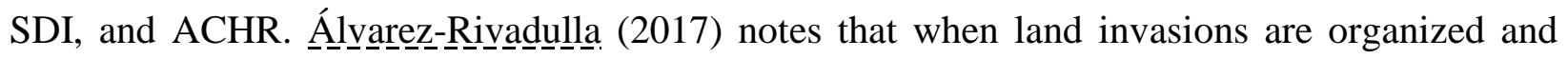
planned in advance, squatter organizations often 'imitate' formal urban planning by subdividing the land into streets and parcels and reserving land for public spaces and community facilities, with the expectation that the settlement may eventually be integrated into the formal city (64-65). 
Urban upgrading by ACHR or provision of neighborhood-level sanitation by OPP involves organizing the provision of long-term public goods through community participation, which aligns with the broad definition of planning discussed above. To the extent that these organizations do help move away from clientelism, the fact that they perform planning-like functions indicates a potential role for professional planners in facilitating a transition from clientelism.

The idea that professionally trained urban planners might offer their expertise directly to individual urban communities rather than city governments has a long history (Davidoff 1965), but in the context of informal settlements, the relationship between professionals and communities is often challenging. Organizations like SDI, while open to professional help, are often resistant to domination by outside professionals (Mitlin 2008). Mitlin (2013) discusses some of the challenges with regard to the 'co-production' of solutions between professionals and communities. Professionals are often expected to arrive with 'solutions', despite a lack of sufficient local knowledge. They are expected to act as intermediaries between communities and the state, a role they may not be equipped to play. Academics and consultants often have their own agenda, such as the preparation of research papers or reports, which differ from those of communities. Mitlin lists strategies that SDI uses to better manage the relationship between communities and professionals, including getting involved in the training and recruitment of professionals, and maintaining clear boundaries between professionals and communities, such that communities can maintain control over projects.

\section{Conclusion and areas for future research}

In order for planning to have a positive impact on the urban poor in developing democracies, planners must recognize the sociopolitical order underlying urban informality, rather than treating informality simply as the outcome of a lack of planning. The multidisciplinary 
literature explored above suggests that planners need to develop an understanding of clientelism and its role in the provision of urban land and services, and of why both the politically powerful patrons and the residents of the informal settlements themselves may resist change to formal service delivery or land use planning. The literature indicates that while clientelism provides the poor with some access to the state, it also prevents them from participating fully in democracy, and hinders the long-term provision of public goods.

The literature from political science, anthropology, and sociology on clientelism in informal urban settlements is extensive, and planners, planning researchers, and urban policymakers working on urban informality can benefit from being conversant in it. National governments and international organizations can use insights from this literature to refine their support to cities, beyond simply providing technical capacity building or budgetary support for politically 'naïve' urban planning and management.

Still, this review also suggests gaps in the literature. The literature identifies instances in which clientelism has declined in favor of a more formal, programmatic system of land and service provision, but lessons for planning are not obvious, and more research into the role of planners is needed in some of these cases. Even beyond these specific instances, it is likely that some planning initiatives around the world have been more effective than others in understanding and operating within clientelistic environments, even if they have not brought about such transitions. Researchers could aim to unearth these hidden minor successes, which could inform the training of planners, and help diminish the vast gap between the expectations placed on planning in developing democracies and its limited positive impact so far. 


\section{References}

Adam, Abdul-Wahid. 2013. "Perceptions of Slum Dwellers and Municipal Officials on Factors Impacting the Provision of Basic Slum Services in Accra, Ghana.” Master's Thesis, The Hague, The Netherlands: Erasmus University - International Institute of Social Studies.

AlSayyad, Nezar. 2004. “Urban Informality as a 'New’ Way of Life.” In Urban Informality: Transnational Perspectives from the Middle East, Latin America, and South Asia, edited by Ananya Roy and Nezar AlSayyad. Vol. Transnational perspectives on space and place. Lanham, Md: Lexington Books.

Álvarez-Rivadulla, María José. 2017. Squatters and the Politics of Marginality in Uruguay. Latin American Political Economy. Cham, Switzerland: Palgrave Macmillan.

Asian Development Bank. 2013. Urban Operational Plan: 2012-2020. http://public.eblib.com/choice/publicfullrecord.aspx?p=3110688.

Auerbach, Adam. 2016. “Clients and Communities.” World Politics 68 (01): 111-48. https://doi.org/10.1017/S0043887115000313.

Auerbach, Adam, Jennifer Bussell, Simon Chauchard, Francesca Jensenius, Gareth Nellis, Mark Schneider, Neelanjan Sircar, et al. 2017. "Rethinking Electoral Politics in India (Draft)."

Auerbach, Adam, and Tariq Thachil. 2014. "Capability, Connectivity, and Co-Ethnicity: The Origins of Political Brokerage in India's Urban Slums.”

Auyero, Javier. 2000. “The Logic of Clientelism in Argentina: An Ethnographic Account.” Latin American Research Review 35 (3): 55-81.

Awal, Mohammed, and Jeffrey W. Paller. 2016. "Who Really Governs Urban Ghana?" http://www.africaresearchinstitute.org/publications/who-really-governs-urban-ghana/. 
Banks, Nicola. 2016. "Livelihoods Limitations: The Political Economy of Urban Poverty in Dhaka, Bangladesh." Development and Change 47 (2): 266-92. https://doi.org/10.1111/dech.12219.

Bénit-Gbaffou, Claire. 2012. "Party Politics, Civil Society and Local Democracy - Reflections from Johannesburg.” Geoforum 43 (2): 178-89. https://doi.org/10.1016/j.geoforum.2011.08.006.

Bénit-Gbaffou, Claire, and Sophie Oldfield. 2014. "Claiming 'Rights' in the African City.” In The Routledge Handbook on Cities of the Global South, edited by Sue Parnell and Sophie Oldfield. London; New York: Routledge, Taylor \& Francis Group.

Benjamin, Solomon. 2005. "Touts, Pirates and Ghosts." Sarai Reader, no. Bare Acts: 242-54.

—. 2008. "Occupancy Urbanism: Radicalizing Politics and Economy beyond Policy and Programs." International Journal of Urban and Regional Research 32 (3): 719-29.

Bhan, Gautam. 2016. In the Public's Interest: Evictions, Citizenship, and Inequality in Contemporary Delhi. University of Georgia Press.

Birch, Eugenie L. 2017. “Urban Informality as a Way of Life.” December. https://youtu.be/G4yh6jwmVFw.

Björkman, Lisa. 2014a. “'You Can’t Buy a Vote': Meanings of Money in a Mumbai Election.” American Ethnologist 41 (4): 617-634.

—.2014b. "Becoming a Slum: From Municipal Colony to Illegal Settlement in Liberalization-Era Mumbai." International Journal of Urban and Regional Research 38 (1): 36-59.

Brusco, Valeria, Marcelo Nazareno, and Susan C. Stokes. 2004. "Vote Buying in Argentina." Latin American Research Review 39 (2): 66-88. 
Burgwal, Gerrit. 1995. Struggle of the Poor: Neighborhood Organization and Clientelist Practice in a Quito Squatter Settlement. Latin America Studies 74. Amsterdam: CEDLA. Chalana, Manish, and Jeffrey Hou, eds. 2016. Messy Urbanism Understanding the "Other" Cities of Asia. Hong Kong: Hong Kong University Press.

Chidambaram, Soundarya. 2011. "Welfare, Patronage, and the Rise of Hindu Nationalism in India's Urban Slums." PhD dissertation, The Ohio State University. http://search.proquest.com/docview/925813415?accountid=14707.

Datta, Ayona. 2012. The Illegal City: Space, Law and Gender in a Delhi Squatter Settlement. Farnham: Ashgate.

Davidoff, Paul. 1965. "Advocacy and Pluralism in Planning." Journal of the American Institute of Planners 31 (4): 331-38.

Davis, Diane E. 2014. "Modernist Planning and the Foundations of Urban Violence in Latin America." Built Environment 40 (3): 376-93. https://doi.org/10.2148/benv.40.3.376.

De, Indranil, and Tirthankar Nag. 2016. "Dangers of Decentralisation in Urban Slums: A Comparative Study of Water Supply and Drainage Service Delivery in Kolkata, India.” Development Policy Review 34 (2): 253-76. https://doi.org/10.1111/dpr.12149.

Elyachar, Julia. 2005. Markets of Dispossession: NGOs, Economic Development, and the State in Cairo. Politics, History, and Culture. Durham, NC: Duke Univ. Press.

Fergusson, Leopoldo, Horacio Larreguy, and Juan Felipe Riaño. 2016. "Political Competition and State Capacity: Evidence from a Land Allocation Program in Mexico."

Follmann, Alexander. 2015. “Urban Mega-Projects for a 'World-Class' Riverfront - The Interplay of Informality, Flexibility and Exceptionality along the Yamuna in Delhi, 
India." Habitat International 45 (January): 213-22.

https://doi.org/10.1016/j.habitatint.2014.02.007.

Fox, Sean. 2014. "The Political Economy of Slums: Theory and Evidence from Sub-Saharan Africa." World Development 54: 191-203. https://doi.org///dx.doi.org/10.1016/j.worlddev.2013.08.005.

Gandhi, Ajay. 2012. “'Informal Moral Economies' and Urban Governance in India.” In Urban Informalities: Reflections on the Formal and Informal, edited by Colin McFarlane and Michael Waibel. Farnham; Burlington, VT: Ashgate.

Gandy, Matthew. 2006. "Planning, Anti-Planning and the Infrastructure Crisis Facing Metropolitan Lagos." Urban Studies 43 (2): 371-96. https://doi.org/10.1080/00420980500406751.

Gay, Robert. 1998. "Rethinking Clientelism: Demands, Discourses and Practices in Contemporary Brazil." Revista Europea de Estudios Latinoamericanos y Del Caribe / European Review of Latin American and Caribbean Studies, no. 65: 7-24.

—. 2006. "The Even More Difficult Transition from Clientelism to Citizenship: Lessons from Brazil." In Out of the Shadows: Political Action and the Informal Economy in Latin America, edited by Patricia Fernandez-Kelly and Jon Shefner. University Park, Pa.: Pennsylvania State University Press.

Gillespie, Tom. 2017. “From Quiet to Bold Encroachment: Contesting Dispossession in Accra's Informal Sector." Urban Geography 38 (7): 974-92. https://doi.org/10.1080/02723638.2016.1191792. 
Goodfellow, Tom. 2012. "State Effectiveness and the Politics of Urban Development in East Africa: A Puzzle of Two Cities, 2000-2010.” London: The London School of Economics and Political Science.

Government of India. 2013. "Twelfth Five Year Plan (2012-2017) - Faster, Sustainable and More Inclusive Growth.” Planning Commission. http://planningcommission.gov.in/plans/planrel/12thplan/pdf/12fyp_vol1.pdf.

Gray, Obika. 2004. Demeaned but Empowered: The Social Power of the Urban Poor in Jamaica. Kingston, Jamaica: University of the West Indies Press,.

Hackenbroch, Kirsten, and Shahadat Hossain. 2012. “"The Organised Encroachment of the Powerful' - Everyday Practices of Public Space and Water Supply in Dhaka, Bangladesh.” Planning Theory \& Practice 13 (3): 397-420. https://doi.org/10.1080/14649357.2012.694265.

Hays, Samuel P. 1974. "The Changing Political Structure of the City in Industrial America." Journal of Urban History 1 (1): 6-38. https://doi.org/10.1177/009614427400100102. Herrera, Veronica Maria Sol. 2017. Water and Politics: Clientelism and Reform in Urban Mexico. University of Michigan Press.

Holland, Alisha. 2017. Forbearance as Redistribution: The Politics of Informal Welfare in Latin America. Cambridge Studies in Comparative Politics. Cambridge, UK; New York, NY: Cambridge University Press.

Huchzermeyer, Marie. 2011. Cities with "Slums": From Informal Settlement Eradication to a Right to the City in Africa. Claremont, South Africa: UCT Press.

Hutchison, Jane. 2007. “The 'Disallowed' Political Participation of Manila's Urban Poor.” Democratization 14 (5): 853-72. https://doi.org/10.1080/13510340701635696. 
Inskeep, Steve. 2011. Instant City: Life and Death in Karachi. New York: Penguin Press.

Jha, Saumitra, Vijayendra Rao, and Michael Woolcock. 2005. "Governance in the Gullies:

Democratic Responsiveness and Leadership in Delhi’s Slums.” World Bank.

Khan, Akhter Hameed. 1992. "Orangi Pilot Project Programs."

https://www.ircwash.org/sites/default/files/822-PKOR92-11567.pdf.

Kitschelt, Herbert, and Steven I. Wilkinson. 2007. "Citizen-Politician Linkages: An Introduction." In Patrons, Clients, and Policies: Patterns of Democratic Accountability and Political Competition, edited by Herbert Kitschelt and Steven I. Wilkinson. Cambridge, UK ; Cambridge University Press,.

Klopp, Jacqueline M. 2012. “Towards a Political Economy of Transportation Policy and Practice in Nairobi." Urban Forum 23 (1): 1-21. https://doi.org/10.1007/s12132-011-9116-y.

Kramon, Eric. 2016. “Electoral Handouts as Information.” World Politics 68 (3): 454-98.

Lall, Somik V. 2013. Planning, Connecting, and Financing Cities-Now: Priorities for City Leaders. Washington, DC: World Bank Group.

Lall, Somik V., J. Vernon Henderson, and Anthony J. Venables. 2017. Africa's Cities: Opening Doors to the World. Washington, DC: World Bank.

Lapomarda, Vincent A. 1970. "Maurice Joseph Tobin: The Decline of Bossism in Boston." The New England Quarterly 43 (3): 355-81. https://doi.org/10.2307/363303.

Ledeneva, Alena. 2018. "Introduction: The Informal View of the World - Key Challenges and Main Findings of the Global Informality Project." In The Global Encyclopaedia of Informality, Volume 1, edited by Alena Ledeneva. Vol. 1. UCL Press. 
Levenson, Zachary. 2017. "Precarious Welfare States: Urban Struggles over Housing Delivery in Post-Apartheid South Africa.” International Sociology 32 (4): 474-92. https://doi.org/10.1177/0268580917701586.

McFarlane, Colin, and Michael Waibel. 2012. "Introduction: The Informal-Formal Divide in Context." In Urban Informalities: Reflections on the Formal and Informal, edited by Colin McFarlane and Michael Waibel. Farnham; Burlington, VT: Ashgate.

Mitlin, Diana. 2008. "With and beyond the State - Co-Production as a Route to Political Influence, Power and Transformation for Grassroots Organizations." Environment and Urbanization 20 (2): 339-60. https://doi.org/10.1177/0956247808096117.

—. 2013. "A Class Act: Professional Support to People's Organizations in Towns and Cities of the Global South." Environment and Urbanization 25 (2): 483-99. https://doi.org/10.1177/0956247813488862.

—. 2014. "Politics, Informality and Clientelism - Exploring a pro-Poor Urban Politics." 34. ESID Working Papers. Effective States and Inclusive Development Research Centre (ESID).

— 2018. "Beyond Contention: Urban Social Movements and Their Multiple Approaches to Secure Transformation." Environment and Urbanization 30 (2): 557-74. https://doi.org/10.1177/0956247818791012.

Mitlin, Diana, and Jan Mogaladi. 2013. "Social Movements and the Struggle for Shelter: A Case Study of EThekwini (Durban)." Progress in Planning 84 (August): 1-39. https://doi.org/10.1016/j.progress.2012.12.001.

Muller, Wolfgang C. 2007. "Political Institutions and Linkage Strategies." In Patrons, Clients, and Policies: Patterns of Democratic Accountability and Political Competition, edited by 
Herbert Kitschelt and Steven I. Wilkinson. Cambridge, UK ; Cambridge University

Press,.

Nahiduzzaman, K.M. 2006. "Housing the Urban Poor: Planning, Business and Politics - A Case Study of Duaripara Slum, Dhaka City, Bangladesh.” Norway: Norwegian University of Science and Technology.

Nathan, Noah L. 2016. "Does Participation Reinforce Patronage? Policy Preferences, Turnout and Class in Urban Ghana.” British Journal of Political Science, 1-27. https://doi.org/10.1017/S0007123416000351.

Ozlu, Mehmet Onur, Abebaw Alemayehu, Megha Mukim, Somik V. Lall, Oliver Thomas Kerr, Olga Kaganova, Chloe Oliver Viola, et al. 2015. "Ethiopia - Urbanization Review: Urban Institutions for a Middle-Income Ethiopia.” World Bank Group. http://documents.worldbank.org/curated/en/543201468000586809/EthiopiaUrbanization-review-urban-institutions-for-a-middle-income-Ethiopia.

Paller, Jeffrey W. 2014. "Informal Institutions and Personal Rule in Urban Ghana.” African Studies Review 57 (3): 123-42.

—. 2016. "Informal Practices of Accountability in Urban Africa." Oxford University Press. https://doi.org/10.1093/obo/9780199756223-0172.

—. 2017. "The Contentious Politics of African Urbanization." Current History 116 (790): 163-69.

Pasotti, Eleonora. 2010. Political Branding in Cities : The Decline of Machine Politics in Bogotá, Naples, and Chicago. Cambridge: Cambridge University Press. 
Patel, Bimal. 2015. "Managing Politics of Urban Planning.” April 22, 2015.

http://www.livemint.com/Opinion/VlE1ANfbnunacRpaojBU2N/Managing-politics-ofurban-planning.html.

Patel, Sheela, Jockin Arputham, and Sheridan Bartlett. 2016. "“"We Beat the Path by Walking": How the Women of Mahila Milan in India Learned to Plan, Design, Finance and Build Housing." Environment and Urbanization 28 (1): 223-40. https://doi.org/10.1177/0956247815617440.

Perlman, Janice E. 1976. The Myth of Marginality: Urban Poverty and Politics in Rio de Janeiro. Berkeley: University of California Press.

Pethe, Abhay, Ramakrishna Nallathiga, Sahil Gandhi, and Vaidehi Tandel. 2014. "Re-Thinking Urban Planning in India: Learning from the Wedge between the de Jure and de Facto Development in Mumbai." Cities 39: 120-32.

Piliavsky, Anastasia, ed. 2014. Patronage as Politics in South Asia. New York: Cambridge University Press.

Rajack, Robin, Abhay Pethe, Peter Ngau, and Shrikant Barhate. 2013. "The Political Economy of Urban Land Management: Evidence from Mumbai and Nairobi.” Annual World Bank Conference on Land and Poverty 2013.

Robins, Steven L. 2008. From Revolution to Rights in South Africa: Social Movements, NGOs \& Popular Politics after Apartheid. Woodbridge [England]; James Currey.

Rojo, Guadalupe, Subhash Jha, and Erik Wibbels. 2014. "Political Networks, Clientelism and Public Goods: Evidence from Slums in Udaipur, India.” https://sites.duke.edu/wibbels/files/2014/10/RojoJhaWibbels.pdf. 
Roy, Ananya. 2012. "Urban Informality: The Production of Space and Practice of Planning." In The Oxford Handbook of Urban Planning, edited by Rachel Weber and Randall Crane, $691-705$.

Sanyal, Bishwapriya. 2005. "Hybrid Planning Cultures: The Search for the Global Cultural Commons." In Comparative Planning Cultures. London, U.K.: Routledge. http://ebookcentral.proquest.com/lib/upenn-ebooks/detail.action?docID=801673.

Satterthwaite, David, and Diana Mitlin. 2013. Reducing Urban Poverty in the Global South. Hoboken: Taylor and Francis. http://www.123library.org/book_details/?id=103777.

Scheiner, Ethan. 2007. "Clientelism in Japan: The Importance and Limits of Institutional Explanations." In Patrons, Clients, and Policies: Patterns of Democratic Accountability and Political Competition, edited by Herbert Kitschelt and Steven I. Wilkinson. Cambridge, UK ; Cambridge University Press,.

Shami, Mahvish, and Hadia Majid. 2014. "The Political Economy of Public Goods Provision in Slums: Preliminary Results from a Field Study in Urban Pakistan.” Working Paper. London: International Growth Centre.

Shannon, William V. 1969. "The Political Machine I: Rise And Fall The Age Of The Bosses." American Heritage, June 1969. http://www.americanheritage.com/content/politicalmachine-i-rise-and-fall-age-bosses.

Shefner, Jon. 2006. “'Do You Think Democracy Is a Magical Thing?' From Basic Needs to Democratization in Informal Politics." In Out of the Shadows: Political Action and the Informal Economy in Latin America, edited by Patricia Fernandez-Kelly and Jon Shefner. University Park, Pa.: Pennsylvania State University Press. 
Silva, Rita de Cacia Oenning da, and Kurt Shaw. 2012. "Hip-Hop and Sociality in a Brazilian Favela." In Urban Informalities: Reflections on the Formal and Informal, edited by Colin McFarlane and Michael Waibel. Farnham; Burlington, VT: Ashgate.

Syagga, P., W. Mitullah, and S. Karirah-Gitau. 2002. "A Rapid Economic Appraisal of Rents in Slums and Informal Settlements." m. Government of Kenya and UN-HABITAT Collaborative Nairobi Slum Upgrading Initiative.

Tomsa, Dirk, and Andreas Ufen, eds. 2013. Party Politics in Southeast Asia: Clientelism and Electoral Competition in Indonesia, Thailand and the Philippines. Routledge Contemporary Southeast Asia Series 55. New York: Routledge.

UN-Habitat. 2009. Planning Sustainable Cities: Global Report on Human Settlements 2009. Global Report on Human Settlements. https://unhabitat.org/books/global-report-onhuman-settlements-2009-planning-sustainable-cities/.

—.2010. State of the World's Cities 2010/2011-Cities for All. http://unhabitat.org/books/state-of-the-worlds-cities-20102011-cities-for-all-bridging-theurban-divide/.

—2014. State of African Cities Re-Imagining Sustainable Urban Transitions. State of Cities - Regional Reports. UN-Habitat. https://unhabitat.org/books/state-of-african-cities2014-re-imagining-sustainable-urban-transitions/.

United Nations. 2016. “The New Urban Agenda.” Habitat III. 2016. http://habitat3.org/the-newurban-agenda/.

Watson, Vanessa. 2009. "Seeing from the South: Refocusing Urban Planning on the Globe's Central Urban Issues." Urban Studies 46 (11): 2259-75. https://doi.org/10.1177/0042098009342598. 
Weinstein, Liza. 2014. The Durable Slum: Dharavi and the Right to Stay Put in Globalizing Mumbai. Minneapolis, MN: University of Minnesota Press.

Weitz-Shapiro, Rebecca. 2012. "What Wins Votes: Why Some Politicians Opt Out of Clientelism.” American Journal of Political Science 56 (3): 568-83. https://doi.org/10.1111/j.1540-5907.2011.00578.x.

Wit, Joop de. 2017. Urban Poverty, Local Governance and Everyday Politics in Mumbai. First South Asia edition. Cities and the Urban Imperative. Abingdon, Oxon; New York: Routledge, Taylor \& Francis Group.

Wit, Joop de, and Erhard Berner. 2009. "Progressive Patronage? Municipalities, NGOs, CBOs and the Limits to Slum Dwellers' Empowerment." Development and Change 40 (5): 948; 948.

World Bank. 2003. World Development Report 2004: Making Services Work for Poor People. Washington, D.C.: World Bank. . 2017. World Development Report 2017: Governance and the Law. Washington, DC.: World Bank Group. 